\title{
Legal Conditions for Investments in Renewable Energy in the Overburden Disposal Areas in Poland
}

\author{
Marta Resak ${ }^{1}$, Barbara Rogosz ${ }^{1, *}$, Jacek Szczepiński ${ }^{1}$ and Mariusz Dziamara ${ }^{2}$ \\ 1 Poltegor-Institute, 51-616 Wroclaw, Poland; marta.resak@igo.wroc.pl (M.R.); \\ jacek.szczepinski@igo.wroc.pl (J.S.) \\ 2 PAK Konin Lignite Mine S.A., 62-540 Kleczew, Poland; dziamara.mariusz@kwbkonin.pl \\ * Correspondence: barbara.rogosz@igo.wroc.pl
}

check for updates

Citation: Resak, M.; Rogosz, B.; Szczepiński, J.; Dziamara, M. Legal Conditions for Investments in

Renewable Energy in the

Overburden Disposal Areas in

Poland. Sustainability 2022, 14, 1065. https://doi.org/10.3390/su14031065

Academic Editor: Idiano D'Adamo

Received: 6 December 202

Accepted: 13 January 2022

Published: 18 January 2022

Publisher's Note: MDPI stays neutral with regard to jurisdictional claims in published maps and institutional affiliations.

Copyright: (C) 2022 by the authors. Licensee MDPI, Basel, Switzerland. This article is an open access article distributed under the terms and conditions of the Creative Commons Attribution (CC BY) license (https:// creativecommons.org/licenses/by/ $4.0 /)$.

\begin{abstract}
The article analyzes opportunities of locating large-scale wind or solar farms in overburden disposal areas, formed as a result of opencast lignite mining. Its main purpose is to present different conditions and limitations for such investments in post-mining regions. The most important aspects include wind or sunlight conditions, geotechnical conditions of the overburden disposal areas where soil and rock materials were deposited during many years of lignite mining and local spatial planning conditions defined by local governments. These, and other conditions cause that the wind or photovoltaic plant investment in the overburden disposal area, might create a challenging process. The legal requirements are discussed in detail, regarding spatial, environmental and infrastructural characteristics of the overburden dumping sites situated inside Jóźwin II B and Jóźwin IIA open pits belonging to the PAK Konin Lignite Mine S.A. located in the west-central part of Poland. The results demonstrate that among the legal conditions for the construction of renewable energy plants, the most restrictive limitation concerns wind farms and precludes the rehabilitation of Konin overburden dumps in this direction. Until the construction of wind farms is legally impossible at closer distances to residential buildings, photovoltaic power plants are the only option for the development of post-mining areas towards large-scale renewable power generation.
\end{abstract}

Keywords: overburden disposal area; reclamation; wind turbine; photovoltaic plant; legal regulations

\section{Introduction}

In Poland, many dumps and heaps have been formed as a result of lignite surface mining that intensified in the second half of the 20th century. These dumps and heaps cover huge areas, and their reclamation has largely been limited to agriculture, forestry, and sometimes public leisure amenities. It is far more unusual to find construction of any kind being built on reclaimed mining spoil. It would be reasonable to use these largelignite post-mining sites for renewable energy generation, as the Europe's Green Deal strategy [1] involves a number of challenges linked to a need for the European energy sector to undertake action, which will result in significantly higher shares of renewable energy sources in an integrated energy system $[2,3]$.

A fundamental aim of any wind or solar farm investor is to maximize energy production, minimize capital and operating costs, and stay within constraints imposed by the law in order to obtain construction and operation permits for their power plant. The article presents an overview of critical considerations in wind farm and solar farm location within mining spoil dumps and heaps since such developments pose serious challenges to investors. These challenges relate to natural conditions in terms of construction and potential power generation, grid connection limitations and other technical issues; local spatial planning, health, safety and environmental concerns are of the upmost importance. Legal regulations should be treated as the overriding element that determines the other fields and puts actual limits to the development of renewable energy. The location of 
large-scale installations for the production of renewable energy in post-mining dumps is basically subject to the same legal regulations as their location in other areas, except for the fact that it is additionally required to reclaim post-mining areas after the end of mining activities.

The overall state of development of renewable energy in Poland [4] and legal principles standing behind the sustainability of this sector's expected growth [5] has been recently summarized. Other publications cover basic legal acts regulating the issues of renewable energy sources and business activities related to the energy sector [6], analysis of typical development and implementation stages for RES investments, including issues related to obtaining relevant decisions, administrative permits and related investment barriers [7] and legal principles of connecting a source of renewable energy to the grid [8].

In the case of wind farms, there are many factors influencing the choice of their location which need to be discussed before the investment starts [9]. The conceptual and formal stages of the investment process are described in the Code of Good Practice for the wind power industry [10]. Several authors have focused on a discussion of the most important regulations of the Polish law related to the wind energy sector [11,12], description of procedures and activities that have to be carried out in order to complete the process of environmental impact assessment for wind farms [13] and documentation of geological and engineering conditions [14]. Interactions between wind turbines and soil where they are constructed have been recognized as complex phenomena [15]. A geological survey program and types of foundations for tall wind turbine towers standing on weak ground have been proposed [16].

For the Utility-Scale Solar Photovoltaic Power Plants a Project Developer's Guide (2015) has been prepared [17]. It covers aspects of the preparation process for a solar power plant construction project and provides guidance on the entire process, including identification, plant design, energy yield, permits, licenses, contractual arrangements, and financing. Several authors have discussed the legal regulations applicable for the construction of photovoltaic power plants in Poland, steps that must be taken by an investor to implement an investment [18-20] and procedures of environmental impact assessment for such plants [21]. The study "Rynek Fotowoltaiki w Polsce 2019" analyzes what influences the productivity of a photovoltaic installation and shows some legal difficulties in the investment process [22].

A proposal for a geological survey program including field and laboratory surveys and criteria for the selection of a suitable installation site for a solar farm have been presented [23]. The possibilities of a photovoltaic system construction in anthropogenic (post-flotation) areas in the context of revitalization of the facility, as well as in the context of an impact of soil and weather conditions on the installation works, have been suggested as worth consideration [24].

The proper location is a rather complex issue and affects both the possibility of obtaining a building permit and the profitability of the future investment. For the purpose of searching for locations for renewable power plants, geoinformatic tools can be used. Geoinformatic studies try to evaluate spatial effects of adopting different criteria for renewable power plant siting: environmental, social, technical criteria and energy resource availability [25-29]. Nevertheless, these studies can only play a role in the initial phase of the search for the location. Usually, the analysis of the use of these tools do not take into account many detailed legal factors that are typical only for a given place and may be decisive for implementation of an investment or lack of this possibility. Each and every time, individual consideration is necessary, especially when one wants to construct a plant in untypical conditions such as post-mining areas.

The aim of this paper is to widely analyze the legal possibilities of implementing investments in renewable energy sources in post-mining dumps and to refer provisions of the applicable laws to the actual locations within the mining dumps of the Konin Lignite Mine in the Wielkopolska region (voivodship) in the west-central part of Poland (Figure 1). As the study area is currently a fossil fuel-dependent region, it is included in 
a territorial just transition plan pursuing the objectives of the European Green Deal and will be supported from the Just Transition Fund in order to adapt to the energy and climate transition processes [30].

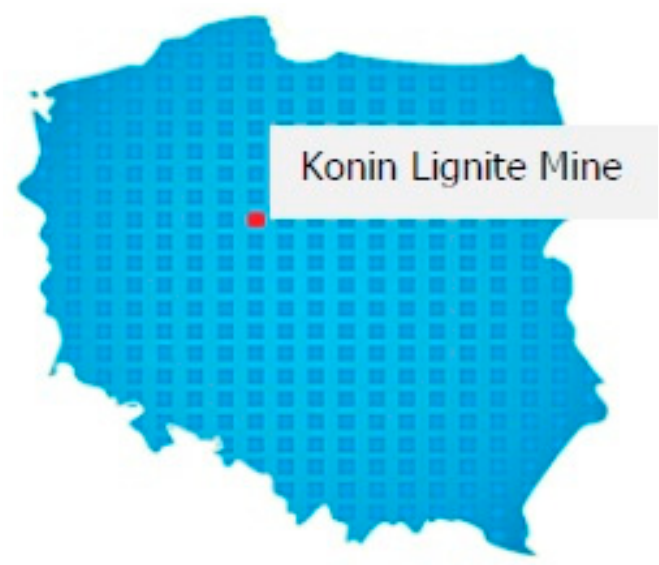

Figure 1. Location of the study area.

This article has been developed as a part of the SUMAD project entitled "Sustainable Use of Mining Waste Dumps", funded by the European Commission's Research Fund for Coal and Steel and co-financed by the Polish Ministry of Science and Higher Education.

\section{Materials and Methods}

This chapter aims at a summary of the binding requirements for wind and solar farm locations within the post-mining areas in order to provide a solid background for the analysis of the selected study sites in west-central Poland.

\subsection{Reclamation as a First Stage}

The first stage of repairing areas affected by mining activities is their reclamation. The land reclamation is the responsibility of a mining company, while developing the land for future non-mining activities is a responsibility of the future user of the reclaimed area. In Poland, there are several reclamation directions usually adopted for lignite opencast mining areas such as: agriculture, forests, sport and recreation, water reservoirs. Nevertheless, there are many other possibilities for reclamation. If it is anticipated that former mining areas, including overburden disposal areas, will be used for renewable energy generation, a relevant direction of reclamation must be accepted and applied. In this case the reclamation process will be limited to technical activities consisting in the appropriate preparation of land surface and securing technical infrastructure facilities. However, it is also possible to construct renewable energy installations after reclamation of land to for example agricultural land but then the reclaimed land must be reclassified from agricultural use to a different type of use that permits the construction of energy generation plants.

It is required by legal regulations that some reclamation planning is undertaken before mining starts and the reclamation activities are carried out at all stages of mining activity. The envisaged method of liquidation of the mining plant and land reclamation after mining operations should be already specified at the stage of applying for a deposit extraction license. The provisions regarding the planned reclamation of post-mining areas need to be specified in two documents: the deposit development project [31] and the mining plant operation plan [32].

A local government authority that determines the degree of limitation or loss in use value of land and designates an entity obliged to reclamation of land, indicates directions and deadline of reclamation is a starost (an administrator of a district; districts consist of municipalities). A planned direction of reclamation should be consistent with the intended use resulting from the provisions of the local land use plan or municipal study of spatial 
conditions, therefore the decision of the starost has to be consulted with a mayor of a local municipality where the mine is located. The starost also issues a decision recognizing reclamation as completed which enables [33] reclassification of the land according to the accepted manner of its use after the reclamation.

\subsection{Overview of Requirements for a Wind Farm Location}

Studies related to determination of wind turbine locations and integration of wind farms into the power grid and local environment should analyze a whole variety of issues from wind characteristics and technical limitations to local spatial planning and ecological constraints. The summary of major influencing factors is presented in Table 1.

\subsubsection{Wind Characteristics}

Wind speed and direction at a given point is influenced by a number of factors which can include: topography, air temperature, local atmosphere equilibrium, type of land cover (roughness), presence of water bodies, all kinds of buildings, large tree or other obstacles. Long-term distributions of wind speed and the resulting power output of a wind turbine must be identified at the very beginning of an investment process. Usually, at least a one-year-long wind monitoring study is performed with use of wind monitoring masts. The wind measurement data (additionally, some data on weather may be collected) from masts are continuously gathered at regular time intervals without interruption. Afterwards, the measurement data is processed and evaluated and then compared to long-term meteorological data, e.g., data from adjacent weather stations, to assess whether the site is suitable for the erection of a wind farm. Moreover, this analysis should help identify the optimal siting and sizing of wind turbines in order to maximize annual wind power generation.

\subsubsection{Rights to the Land}

A wind farm investor must secure a legal title to the land on which a wind farm is to be built (e.g., ownership, tenancy, lease, limited property right or obligation, giving the right to perform construction works). The investors will not obtain a building permit, and therefore will not implement the planned investment if they do not prove their right to use the property for construction purposes.

\subsubsection{Geotechnical Conditions}

While applying for a building permit for a wind farm an investor has to develop a proper construction design along with an obligatory geotechnical opinion which determines geotechnical category of an object to be constructed. Objects such as wind turbines are classified in the third geotechnical category and additionally require preparation of: ground investigation report, geotechnical design report and geological-engineering documentation. Due to the necessity to prepare the above-mentioned documents, the ground on which wind turbines are to be placed requires detailed geotechnical studies and analyzes, drilling, laboratory tests and modeling.

A ground investigation report includes a description of methodology of field and laboratory soil tests, their results and interpretation, a geological model and a summary of the derived geotechnical data values for each layer. Geotechnical design report includes a forecast of changes in the properties of soils over time, determines the calculated geotechnical parameters, the partial safety factors for geotechnical calculations and impacts from the ground as well as adopting a ground calculation model, and, finally, includes calculations of bearing capacity, ground subsidence and general stability. It also considers many aspects such as determining required foundation type, harmful impacts of groundwater on the constructed object and methods of counteracting these threats, determining the scope of required monitoring of the constructed object, the neighboring objects and the surroundings in order to identify possible threats to the construction. 
What is more, for the installation of wind turbines it is necessary to perform detailed geological-engineering documentation in order to determine existing geological structures, geological-engineering and hydrogeological conditions, suitability of the studied area for the specified construction purpose, forecast of changes in the environment. In practice, geological-engineering documentation contains similar elements to the ground investigation report, but the former is subject to approval by the appropriate geological administration authority.

\subsubsection{Grid Limitations}

\section{Grid Connection Conditions}

Once harnessed, electricity generated from a wind farm needs to be connected to the distribution grid so that it can be transported to end users. On sites with strong wind, investors usually prefer to establish wind farms of substantial sizes. In order to avoid grid overload due to the power outputs of large wind farms, the grid operators are conservative about the integration of new power plants into the existing grid and may impose limits on the maximum installed capacities in certain regions in Poland. The wind farm investor must secure their legal and physical access rights for the transmission of the electricity to the grid by obtaining the technical conditions of the grid connection from the enterprise which operates the grid. For this purpose, the investor shall submit an application for determining the grid connection conditions. The grid operator sets a template application form. The application usually contains technical characteristics of the planned installation, the legal title to the land on which it is to be erected and the requirements concerning connecting this installation to the grid.

\section{Distance to Electricity Transformer Stations}

The wind power plant must be connected to a so-called main power point (główny punkt zasilajacy-GPZ), i.e., a transformer station. It often happens that the nearest GPZ is located many kilometers from a power plant, which generates huge additional expenses for a construction of a transmission line. The expenses depend very little on the size of the investment. This means that the profitability of such connection depends on the size of the connected power-the higher it is, the greater the amount of electricity will be divided into costs. This means that the installation of small power plants may be unprofitable due to the huge cost of connecting to the gird.

\subsubsection{Transport Limitations}

Some locations may be logistically inaccessible or very difficult to access due to the need to deliver bulky items. Their weight can hinder transport on some roads, especially over bridges. The use of very large elements in wind power plant construction makes it necessary to locate the wind farm so that it is possible to choose the route most appropriate for transportation of such parts. It cannot lead through densely built-up areas with sharp road turns. The location must also take into account the need to reach the site by a crane that will assemble the wind turbine elements.

\subsubsection{Spatial Planning Limitations}

The investor must obey a local land use plan enacted by the Municipal Council and this plan must clearly indicate a possibility of a wind power plant construction. Non-compliance with the local land use plan may result in the refusal of a building permit. Excerpts from the local land use plan, which confirms the provisions of the plan, may be requested by the investor from the relevant local authority. The excerpt from the relevant land use plan is required to obtain a building permit, a decision on environmental conditions or determination of grid connection technical conditions. In the case of an absence of the local land use plan, the investor has to postpone their investment until the local plan is prepared and accepted by the Municipal Council. In the current legal order, there is no possibility of 
constructing a wind farm on the basis of a zoning and land use decision, which determines land use conditions individually for a specific plot of land.

Distance to Residential Buildings and Nature Protection Areas

The distance at which wind farms can be located and built from a residential building (or a mixed-function building, which includes a residential function) and from protected areas of natural value (such as national parks, nature reserves, landscape parks and Natura 2000 sites) and promotional forest complexes (there is 25 such complexes around Poland) must be equal to or greater than 10 times the height of the wind power plant measured from ground level to the highest point of the plant, including all technical elements, i.e., a rotor with blades. In practice, this distance has to be about $1.5-2 \mathrm{~km}$ from residential buildings/nature protection areas or even more. The distance is taken into account by local authorities when preparing, changing and adopting local land use plans.

\section{Limitations to Investment on Rural Land}

If the land reclaimed after mining activities which the investor intends to use for locating the wind power plant is currently used for agricultural purposes, it has to be reclassified for non-agricultural use, with cost and time implications. It applies only to the land intended for access roads, maneuvering yards and overground parts of wind power plant's foundations. The remaining area can be freely used for agricultural purposes. If the land is designated solely for agricultural use in the local land use plan, in order to use it for wind energy generation the plan needs to be changed by municipal authorities, i.e., the investor has to submit an application for the land use plan change. Then, the land may be excluded from agricultural use. For lands reclaimed for agricultural purposes such exclusion from agricultural use is always required no matter what class these lands represent.

\section{Protected Landscapes}

Landscape protection is an issue belonging to both spatial planning and environmental protection. The basic instruments of landscape protection are the specific legal forms of nature protection, in particular landscape parks and protected landscape areas. In these protected areas, there can be landscape protection zones designated with a number of prohibitions and restrictions on spatial development which aim at maintaining the characteristic features of the landscape, e.g., the prohibition of construction of new objects may be imposed. Apart from the prohibitions and restrictions set for the landscape protection zones, there can be other restrictions on construction formulated for landscape parks and protected landscape areas-for the whole area or for some specific parts mentioned below. These possible prohibitions are:

- The implementation of projects that may have a significant impact on the environment;

- locating construction objects within a $100 \mathrm{~m}$ wide strip from shores of rivers, lakes and other water reservoirs, except for facilities for water tourism, water management or fishing;

- locating construction objects within a $200 \mathrm{~m}$ wide strip from cliff edges and in a seashore technical strip.

It has to be underlined that all of the above mentioned prohibitions are not generally applicable rules - they are formulated individually for each landscape park, each protected landscape area and each landscape protection zone.

The influence of an investment on landscape should be analyzed in frame of the procedure of acquiring a decision on environmental conditions of the investment (see below). Moreover, in local land use plans, boundaries and ways of developing priority landscapes that are indicated by regional landscape audits (obligatorily prepared by regional authorities), must be included and therefore influence on landscape protection in certain area. 
Distance to Public Roads

A minimum distance of a constructed objects from public roads depends on a type of road and a type of surrounding area. Within urban and rural built-up areas the minimum distances are:

- $30 \mathrm{~m}$ for highways;

- $20 \mathrm{~m}$ for expressways;

- $10 \mathrm{~m}$ for national roads;

- $8 \mathrm{~m}$ for regional roads;

- $6 \mathrm{~m}$ for municipal roads.

Outside built-up areas the minimum distances are:

- $50 \mathrm{~m}$ for highways;

- 40 m for expressways;

- $25 \mathrm{~m}$ for national roads;

- $20 \mathrm{~m}$ for regional roads;

- $15 \mathrm{~m}$ for municipal roads.

In particular cases, a location of a constructed object next to the road at a smaller distance than the distance specified above may take place only with a consent of a relevant road administrator, issued before the investor applies for a building permit.

\section{Distance to Overhead Power Transmission Lines}

On the one hand, proximity of a power line is desirable from an economic point of view, while on the other hand, wind turbines must be away from power lines so as not to interfere with their operation and maintenance. Each power distribution company indicates the minimum distances that must be kept from the constructed wind turbines. These distances are usually based on a wind tower height and a rotor diameter. The distances are different for each distribution company and are generally dependent on the power line voltage. Requirements for the minimum distance of wind turbines from overhead power lines in force at ENERGA-OPERATOR company (operating in central and northern Poland) are described below as an example.

A technical lane should be marked along the power line with a voltage of up to $45 \mathrm{kV}$, in which no wind turbine element (in particular no turbine blade) can be located. The axis of symmetry of the technical lane should be marked by the columns. The required widths of the technical lanes for a given type of line are:

- Low voltage lines (up to $1 \mathrm{kV}$ )

- $\quad 20 \mathrm{~m}$ for single lines

- $\quad 25 \mathrm{~m}$ for double lines

- Medium voltage lines (up to $45 \mathrm{kV}$ )

- $\quad 25 \mathrm{~m}$ for single lines

- $\quad 30 \mathrm{~m}$ for double lines

In the case of lines of a voltage above $45 \mathrm{kV}$, the required distance of a wind turbine from the line depends on whether active vibration protection has been installed at the line:

- if the line does not have vibration dampers, the distance of the wind turbine blade tip from the most external power line should be $3 \mathrm{~d}$;

- if the line has vibration dampers, the distance between the end of the turbine blade and the most external power line should be $d$. where $d$ is the diameter of the circle used by the blades of the wind turbine.

In the case of lines with the highest voltages, $220 \mathrm{kV}$ and above, operated by one company in the area of the whole country, Polskie Sieci Energetyczne S.A., a minimum permissible distance of a wind turbine from a power line, defined as a distance of the most distant element of the wind turbine (tips of the turbine blades) from the axis of the 
overhead power line, is 3 times the diameter $\mathrm{d}$ of the circle used by the blades of the wind turbine $(3 \times \mathrm{d})$.

Usually in local land use plans, along power lines of a given voltage a technical lane of a certain width is defined on both sides of the power line axis. Within the technical lane there are special conditions and restrictions of land use, including the prohibition of construction of wind turbines in a way that some elements of the turbines, including turbine blade tips, are located within the lane. If this not the case, arrangements with a relevant energy distribution company must be made at a stage of applying for a building permit.

\section{Air Traffic Conditions}

If a wind farm is to be located in the near distance from an aviation ground facility, an area with limited development of constructed objects may be designated and implemented in the local land use plan after the required agreements with the Civil Aviation Authority are completed. The Civil Aviation Authority also issues opinions on the possibility of locating the investment due to the height of the object within the area with limited development of constructed objects and can grant consent to waive the requirements for these areas if the investment does not interfere with the aviation ground facility operations.

Each wind power plant that exceeds a height of $50 \mathrm{~m}$ should be reported to the competent authority supervising military aviation. If it exceeds a height of $100 \mathrm{~m}$ it should also be reported to the President of the Civil Aviation Authority. The mentioned aviation authorities set appropriate notification templates.

\subsubsection{Environmental Conditions}

In order to obtain a building permit for a wind farm an investor may need to and usually has to apply for a decision on environmental conditions of the investment and enclose the investment's information card. The decision on the environmental conditions is required for a construction of wind power plants located in protected areas (i.e., national parks; nature reserves; landscape parks; protected landscape areas; Natura 2000 sites; ecological sites; nature and landscape complexes (Location of wind power plants within nature protection areas such as national parks, nature reserves, landscape parks and Natura 2000 sites is anyway not possible based on the Act of 20 May 2016 on wind farm investments (Journal of Laws of 2016, item 961) [34]) or located outside protected areas but characterized by a total height of more than 30 meters. A local authority decides whether an environmental impact assessment (EIA) is needed in order to issue a decision on environmental conditions of the investment. If so, the relevant procedure is put in motion. For wind farms with a total rated power of more than $100 \mathrm{MW}$ the environmental impact assessment is always needed. If the investor is obliged to conduct an environmental impact assessment (EIA) of environmental, natural as well as social conditions of an investment, it usually includes among others:

- monitoring of living organisms, which the investment can have impact on. In the case of wind power plants, this usually requires the monitoring of birds and bats, less frequently of particular species of amphibians and reptiles or vegetation;

- description of natural components of the environment influenced by the anticipated environmental impact;

- analysis of noise pollution caused by the investment;

- description of the investment's impact on air, soil, water, landscape, climate, material goods, monuments, and people.

Moreover, 1 of the most analyzed impacts of wind turbines is noise pollution. Permissible noise levels during the day and night, related to noise-generating activities, are set at the following levels:

- $45 \mathrm{~dB}$ (day) and $40 \mathrm{~dB}$ (night) for the protection zone " $\mathrm{A}$ " of spa towns and hospital areas located outside towns; 
- $50 \mathrm{~dB}$ (day) and $45 \mathrm{~dB}$ (night) for single-family housing areas, areas of buildings related to permanent or temporary stay of children and adolescents, areas of social care homes and hospital areas in cities;

- $55 \mathrm{~dB}$ (day) and $45 \mathrm{~dB}$ (night) for areas of multi-family housing and collective housing, farm buildings, leisure and recreation areas, residential-commercial areas as well as downtown areas of cities with more than 100,000 inhabitants.

However, the current ban on constructing wind power plants at distances from residential buildings which are smaller than ten times the total plant height ensures that the applicable noise standards are met in any case.

\subsection{Overview of Requirements for a Photovoltaic Farm Location}

Solar farm investors should pay attention to issues such as: southern exposure of the area, lack of shade, appropriate ground conditions, proximity to the grid In addition, photovoltaic devices with an installed capacity of more than $50 \mathrm{~kW}$ always require a building permit. The summary of the requirements is presented in Table 1.

Table 1. Summary of the requirements for wind and solar farm locations within mining spoil dumps.

\begin{tabular}{|c|c|c|}
\hline $\begin{array}{c}\text { Type of a } \\
\text { Requirement/Limitation }\end{array}$ & Wind Farm & Legal Basis \\
\hline $\begin{array}{l}\text { Energy potential related to } \\
\text { meteorological/ } \\
\text { topographic conditions }\end{array}$ & $\begin{array}{l}\text { Energy resource must be investigated in order to } \\
\text { calculate the resulting power output and prove } \\
\text { profitability of an investment }\end{array}$ & - \\
\hline Rights to use the land & Must be secured in order to get a building permit & $\begin{array}{c}\text { Act of } 7 \text { July } 1994 \text { Construction Law (Journal of } \\
\text { Laws of 2020, item 1333) [35] }\end{array}$ \\
\hline $\begin{array}{l}\text { Geotechnical conditions of } \\
\text { the site }\end{array}$ & $\begin{array}{l}\text { Ground investigation report, geotechnical } \\
\text { design report and geological-engineering } \\
\text { documentation must be delivered in addition to } \\
\text { construction design and geotechnical opinion }\end{array}$ & $\begin{array}{c}\text { Act of } 7 \text { July } 1994 \text { Construction Law (Journal of } \\
\text { Laws of 2020, item 1333) [35] } \\
\text { Regulation of the Minister of Transport, } \\
\text { Construction and Maritime Economy of } 25 \text { April } \\
2012 \text { on the determination of geotechnical } \\
\text { conditions for the foundation of buildings } \\
\text { (Journal of Laws of 2012, item 463) [36] } \\
\text { Act of } 9 \text { June 2011 Geological and Mining Law } \\
\text { (Journal of Laws 2020, item 1064) [37] } \\
\text { Regulation of the Minister of the Environment of } \\
18 \text { November 2016 on hydrogeological } \\
\text { documentation and geological-engineering } \\
\text { documentation (Journal of Laws of 2016, } \\
\text { item 2033) [38] }\end{array}$ \\
\hline
\end{tabular}

\begin{tabular}{|c|c|c|c|c|}
\hline 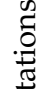 & $\begin{array}{l}\text { Grid connection } \\
\text { conditions }\end{array}$ & \multicolumn{2}{|c|}{$\begin{array}{c}\text { Must be agreed with regional power grid } \\
\text { operator }\end{array}$} & $\begin{array}{c}\text { Act of } 10 \text { April } 1997 \text { Energy Law (Journal of Laws } \\
\text { 2020, item 833) [39] }\end{array}$ \\
\hline 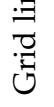 & $\begin{array}{l}\text { Distance to the } \\
\text { nearest electric } \\
\text { substation }\end{array}$ & \multicolumn{2}{|c|}{$\begin{array}{l}\text { Main power point (GPZ) is usually located in the } \\
\text { direct vicinity of the former mine's border }\end{array}$} & - \\
\hline & $\begin{array}{l}\text { ossibility of heavy } \\
\text { erial transportation to } \\
\text { the site }\end{array}$ & \multicolumn{2}{|c|}{$\begin{array}{l}\text { Usually possible; various roads available in the } \\
\text { vicinity of the former mine }\end{array}$} & - \\
\hline 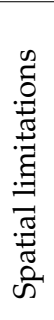 & $\begin{array}{l}\text { Established local land } \\
\text { use plan }\end{array}$ & $\begin{array}{l}\text { The plan must } \\
\text { indicate possibility } \\
\text { for wind power plant } \\
\text { construction }\end{array}$ & $\begin{array}{l}\text { The plan must indicate } \\
\text { possibility for solar } \\
\text { plant construction; if } \\
\text { there is no local land } \\
\text { use plan established, a } \\
\text { zoning and land use } \\
\text { decision for a plot of } \\
\text { land in question must } \\
\text { be obtained }\end{array}$ & $\begin{array}{l}\text { Act of } 27 \text { March } 2003 \text { on spatial planning and } \\
\text { development (Journal of Laws of 2020, } \\
\text { item293) [40] } \\
\text { Act of } 20 \text { May } 2016 \text { on wind farm investments } \\
\text { (Journal of Laws of 2016, item 961) [34] }\end{array}$ \\
\hline
\end{tabular}


Table 1. Cont.

\begin{tabular}{|c|c|c|c|c|}
\hline & $\begin{array}{l}\text { Type of a } \\
\text { Requirement/Limitation }\end{array}$ & Wind Farm & Solar Farm & Legal Basis \\
\hline \multirow{6}{*}{ 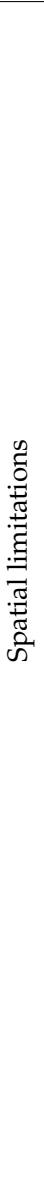 } & $\begin{array}{l}\text { Distance to } \\
\text { residential/nature } \\
\text { protection areas }\end{array}$ & $\begin{array}{l}\text { The distance must be at } \\
\text { least ten times a total } \\
\text { height of a wind power } \\
\text { plant. Therefore, } \\
\text { villages in the } \\
\text { immediate vicinity of } \\
\text { the mine waste dump } \\
\text { may "block" } \\
\text { construction of high } \\
\text { wind turbines }\end{array}$ & $\begin{array}{l}\text { No fixed standards } \\
\text { regarding the } \\
\text { minimum distance }\end{array}$ & $\begin{array}{l}\text { Act of } 20 \text { May } 2016 \text { on wind farm investments (Journal } \\
\text { of Laws of 2016, item 961) [34] }\end{array}$ \\
\hline & $\begin{array}{l}\text { Investment on } \\
\text { rural land }\end{array}$ & $\begin{array}{l}\text { If the land was reclaimed } \\
\text { has to be excluded from a } \\
\text { the class of aq }\end{array}$ & $\begin{array}{l}\text { for agricultural purposes, it } \\
\text { ricultural use (regardless of } \\
\text { ricultural land) }\end{array}$ & $\begin{array}{l}\text { Act of } 3 \text { February } 1995 \text { on the protection of agricultural } \\
\text { and forest land (Journal of Laws of 2017, item 1161) [33] }\end{array}$ \\
\hline & Distance to public roads & $\begin{array}{l}\text { Minimum distances a1 } \\
\text { different types of roads } \\
\text { relevant road adminis }\end{array}$ & $\begin{array}{l}\text { e specified in the Act for } \\
\text { If smaller, a consent of a } \\
\text { trator must be obtained }\end{array}$ & $\begin{array}{c}\text { Act of } 21 \text { March } 1985 \text { on public roads (Journal of Laws } \\
\text { 2020, item 470) [41] }\end{array}$ \\
\hline & $\begin{array}{l}\text { Distance to overhead } \\
\text { power transmission } \\
\text { lines }\end{array}$ & $\begin{array}{l}\text { Minimum distances are } \\
\text { specified by power } \\
\text { distribution companies } \\
\text { and depend on voltage } \\
\text { of the power lines }\end{array}$ & $\begin{array}{l}\text { Location of a power plant } \\
\text { in a close distance to a } \\
\text { power line, especially } \\
\text { within a technical lane } \\
\text { going along the line, must } \\
\text { be agreed with a } \\
\text { relevant power } \\
\text { distribution company }\end{array}$ & $\begin{array}{c}\text { Regulation of the Minister of Infrastructure of } 6 \\
\text { February } 2003 \text { on occupational health and safety during } \\
\text { construction works (Journal of Laws 2003, No. 47, } \\
\text { item 401) [42] } \\
\text { Regulation of the Minister of Health of } 17 \text { December } \\
2019 \text { on the permissible levels of electromagnetic fields } \\
\text { in the environment (Journal of Laws of 2019, } \\
\text { item 2448) [43] }\end{array}$ \\
\hline & Location of air traffic & $\begin{array}{l}\text { Areas with limited } \\
\text { development of } \\
\text { constructed objects due } \\
\text { to air traffic must be } \\
\text { checked in the local land } \\
\text { use plan }\end{array}$ & $\mathrm{n} / \mathrm{a}$ & $\begin{array}{c}\text { Act of } 3 \text { July 2002, Aviation Law (Journal of Laws 2020, } \\
\text { item 1970) [44] }\end{array}$ \\
\hline & $\begin{array}{l}\text { Location of protected } \\
\text { landscape }\end{array}$ & $\begin{array}{r}\text { Priority landscapes may } \\
\text { plans. Restrictions on s } \\
\text { landscape protection zo } \\
\text { landscape parks and pro } \\
\text { binding for local land } \mathrm{u} \\
\text { use d }\end{array}$ & $\begin{array}{l}\text { e indicted in local land use } \\
\text { atial development set for } \\
\text { es (that are designated in } \\
\text { ected landscape areas) are } \\
\text { e plans / zoning and land } \\
\text { cisions }\end{array}$ & $\begin{array}{c}\text { Act of } 24 \text { April } 2015 \text { amending certain acts in connection with } \\
\text { the strengthening of landscape protection tools (Journal of } \\
\text { Laws of 2015, item 774) [45] } \\
\text { Act of } 16 \text { April } 2004 \text { on nature protection (Journal of } \\
\text { Laws of 2020, item 55) [46] }\end{array}$ \\
\hline \multirow{5}{*}{ 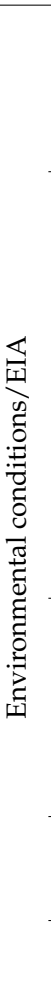 } & $\begin{array}{l}\text { Obtaining decision on } \\
\text { environmental } \\
\text { conditions }\end{array}$ & $\begin{array}{l}\text { Required for wind } \\
\text { power plants of a total } \\
\text { height of more than } 30 \\
\text { m or located within } \\
\text { nature protection areas }\end{array}$ & $\begin{array}{l}\text { Required for photovoltaic } \\
\text { farms covering the area } \\
\text { larger than } 1 \text { ha or } 0.5 \text { ha if } \\
\text { located within a nature } \\
\text { protection area }\end{array}$ & \multirow{5}{*}{$\begin{array}{c}\text { Act of } 20 \text { May } 2016 \text { on wind farm investments (Journal } \\
\text { of Laws of 2016, item 961) [34] } \\
\text { Act of } 27 \text { April } 2001 \text { Environmental Protection Law } \\
\text { (Journal of Laws 2020, item 1219) [47] } \\
\text { Act of } 16 \text { April } 2004 \text { on nature protection (Journal of } \\
\text { Laws of 2020, item 55) [46] } \\
\text { Act of } 3 \text { October } 2008 \text { on the provision of information } \\
\text { about the environment and its protection, public } \\
\text { participation in environmental protection and } \\
\text { environmental impact assessments (Journal of Laws } \\
\text { 2020, item 283) [48] } \\
\text { Regulation of the Council of Ministers of 10 September } \\
\text { 2019 on projects that may significantly affect the } \\
\text { environment (Journal of Laws 2020, item 1333) [49] } \\
\text { Regulation of the Minister of the Environment of 14 } \\
\text { June 2007 on permissible noise levels in the } \\
\text { environment (Journal of Laws of 2019, item 1839) [50] }\end{array}$} \\
\hline & $\begin{array}{l}\text { Location of nature } \\
\text { protection areas }\end{array}$ & $\begin{array}{c}\text { Location of a power } \\
\text { plant within some } \\
\text { nature protection areas } \\
\text { (such as national parks, } \\
\text { nature reserves, } \\
\text { landscape parks and } \\
\text { Natura } 2000 \text { sites) is not } \\
\text { possible. Location } \\
\text { within other nature } \\
\text { protection areas or its } \\
\text { impact on the nearest } \\
\text { nature protection areas } \\
\text { is important in terms } \\
\text { of EIA }\end{array}$ & $\begin{array}{c}\text { Location of a power plant } \\
\text { within a nature protection } \\
\text { area or its impact on the } \\
\text { nearest nature protection } \\
\text { areas is important in terms } \\
\text { of EIA }\end{array}$ & \\
\hline & Acoustic influence & $\begin{array}{l}\text { If a distance between a } \\
\text { wind power plant and a } \\
\text { residential area must be } \\
\text { at least ten times a total } \\
\text { height of the plant, the } \\
\text { noise standards are } \\
\text { always met }\end{array}$ & $\begin{array}{l}\text { Noise analysis may need } \\
\text { to be performed with } \\
\text { regard to permissible } \\
\text { noise levels during the } \\
\text { day and night regarding a } \\
\text { transformer station }\end{array}$ & \\
\hline & $\begin{array}{l}\text { Location of birds and } \\
\text { bats corridors }\end{array}$ & \multicolumn{2}{|c|}{$\begin{array}{l}\text { Monitoring of birds and bats, usually one year-long, is } \\
\text { required for an environmental impact } \\
\text { assessment report }\end{array}$} & \\
\hline & $\begin{array}{l}\text { Location of protected } \\
\text { landscape }\end{array}$ & \multicolumn{2}{|c|}{ Impact on landscape must be analyzed in frame of EIA } & \\
\hline
\end{tabular}




\subsubsection{Solar Radiation Characteristics}

To accurately estimate energy produced from a PV power plant and confirm feasibility of an investment, information is needed on the solar resource and temperature conditions of the site in addition to the layout and technical specifications of the plant components. When assessing the solar radiation at a given site, care must be taken to minimize any shading that will reduce the irradiation received. Shading could be due to mountains or buildings on the far horizon, mutual shading between rows of modules, or shading near the location due to trees, buildings, or overhead cabling. Particular care should be taken to consider any shading that could occur due to future construction projects or by growth of vegetation. Ideally, the site should be flat or on a slight south-facing slope. Such topography makes the installation simpler and reduces the cost of technical modifications required to adjust for undulations in the ground. Solar radiation at a given site must be investigated with regard to the area available to install PV modules, which must be sufficient for a farm to generate enough energy to prove profitability of the investment.

\subsubsection{Rights to the Land}

A photovoltaic farm investor must secure a legal title to the land on which a solar farm is to be built (e.g., ownership, tenancy, lease, limited property right or obligation, giving the right to perform construction works). The investors will not obtain a building permit, and therefore will not implement the planned investment if they do not prove their right to use the property for construction purposes.

\subsubsection{Geotechnical Conditions}

A PV power plant to be constructed on a land reclaimed after overburden dumping will have to be assessed by a geotechnician and possibly classified as the third geotechnical category or at least complex ground conditions of the second category. In both cases, apart from the geotechnical opinion, it will require preparation of three geotechnical studies: ground investigation report, geotechnical design report and geological-engineering documentation (for more details on the contents of these documents see above).

\subsubsection{Grid Limitations}

The location chosen for the investment must enable connection of a PV installation of an indicated size to the existing power grid system. Usually, an installation of up to several dozen $\mathrm{kW}$ can be connected to the low voltage grid and an installation of up to several MW can be connected to the medium voltage gird directly via a transformer. With higher installed powers (more than several MW), it is necessary to construct a power line to the main power point (GPZ), which significantly increases the installation costs, often resulting in lack of economic feasibility of the investment. Although the power distribution company is required to connect each renewable energy installation to the grid, a given line may not have any spare capacity and the extension of the line may be economically unjustified. The PV farm investor must secure their legal and physical access rights for the transmission of the electricity to the grid by obtaining the technical conditions of the grid connection from the enterprise which operates the grid.

\subsubsection{Spatial Planning Limitations}

Provisions in a local land use plan must confirm the possibility of constructing a photovoltaic power plant. The excerpt from the relevant land use plan which confirms the provisions of the plan is required to obtain a building permit, a decision on environmental conditions or determination of grid connection technical conditions. In the case of an absence of the local land use plan, the investor must obtain from mayor/president of a town a zoning and land use decision for a plot of land in question. The decision determines the land use conditions of the land plot. 
Distance to Residential Buildings and Nature Protection Areas

There are no standards determining the minimum distance of solar farms from residential buildings or other buildings intended for permanent residence of people, or nature protection areas. The possible impact of a farm on residents and nature is taken into account when issuing a decision on environmental conditions of the investment.

Limitations to Investment on Rural Land

If the reclaimed post-mining land that the investor intends to use for a photovoltaic plant is currently classified as rural land, then it may need reclassification to non-agricultural use, with cost and time implications. If that rural land is covered by a local land use plan and designated for non-agricultural and non-forest purposes, it can be excluded from agricultural use. If the land is covered by a local land use plan and designated for agricultural use, in order to use it for other purposes the plan needs to be changed by municipal authorities, i.e., the investor has to submit an application for the land use plan change. If the land is not covered by the local land use plan, the investor must first obtain a decision on land use conditions. In the second stage, the land must be excluded from agricultural use. For lands reclaimed for agricultural purposes such exclusion from agricultural use is always required no matter what class these lands represent.

\section{Protected Landscapes}

In the case of photovoltaic plant construction, general requirements of landscape protection are basically the same as for wind farms. Usually, small height (up to several meters) of the photovoltaic structures means that they are noticeable only in the closest area (within a radius of several hundred meters). If so, their impact on landscape is limited.

Distance to Public Roads

In the case of photovoltaic plant construction, general requirements for a minimum distance of a constructed plant from public roads are basically the same as for wind farms. In particular cases, a location of a constructed object next to a road at a smaller distance than specified may take place with the consent of a relevant road administrator, issued before the investor obtains a building permit.

Distance to Overhead Power Transmission Line

Usually in local land use plans, along the power lines of a given voltage a technical lane of a certain width is defined on both sides of the power line axis. Within the technical lane there are special conditions and restrictions of land use, including prohibition of construction of some objects, for instance residential buildings. If constructing technical infrastructures such as photovoltaic panels is not clearly prohibited, usually at a stage of applying for a building permit, arrangements on minimal distances from the power lines should be made with the energy distribution company owning the power lines.

\subsubsection{Environmental Conditions}

In order to obtain a building permit for a photovoltaic farm the investor may need to apply for a decision on environmental conditions of the investment and enclose the investment's information card. The decision on the environmental conditions is required for photovoltaic farms of a total area (including the area of accompanying infrastructure) of not less than:

- $\quad 0.5$ ha in nature protection areas (i.e., national parks; nature reserves; landscape parks; protected landscape areas; Natura 2000 sites; ecological areas; nature and landscape complexes) or in buffer zones of nature protection areas such as national parks; nature reserves and landscape parks;

- 1 ha in areas other than those mentioned above. 
A local authority decides whether an environmental impact assessment is needed before issuing a decision on environmental conditions of the investment. If the investor is obliged to conduct an environmental impact assessment, it usually includes among others:

- the monitoring of living organisms, which the investment can have impact on, particularly birds and bats;

- the description of natural components of the environment, especially protected species, influenced by the anticipated environmental impact;

- the analysis of acoustic (inverters and transformer stations cause noise) and electromagnetic effects of the investment;

- the assessment of the impact of light reflections accompanying photovoltaic investments on birds;

- the description of the investment's impact on people and possible social conflicts.

Regarding the possible impact on neighboring residential areas, potential noise pollution may need to be analyzed. A transformer station can be a potential source of noise related to the operation of a photovoltaic farm. The source of noise may be also associated with power transmission lines. It should be noted that the noise emission applies only to overhead lines with higher voltages (110 kV or more). In the case of cable lines, such phenomena do not occur, and therefore there is also no acoustic influence.

\section{Results}

\section{Meeting the Requirements in the Study Area}

The legal requirements described in detail in the previous chapters have been analyzed regarding spatial, environmental, and infrastructural characteristics of two case study areas selected in the Konin lignite mining region located in the west- central part of Poland (Figure 2):

- an area of ca. 420 ha within the Jóźwin IIB open pit inner overburden disposal area, selected as a potential site for wind or solar power plant location;

- an area of almost 300 ha within the Jóźwin IIA open pit inner overburden disposal area, selected as a potential site for solar power plant location.

At the moment, the Jóźwin II B open pit is still an operating mine. It was opened in 1999. The overburden from Jóźwin IIB open pit was initially dumped in the post-mining excavation of Joźwin II A, in which lignite production ended in 2003. The Joźwin II A post-mining area has been already reclaimed as agricultural land and recreational sites.

At the moment, the lignite production is located in the most eastern part of the Joźwin II B open pit and it will last no longer than 2021. In the most western part of the Jóźwin II B mining area, the internal dump has already been reclaimed and the land no longer belongs to the PAK Konin Lignite Mine S.A. Farther east from the reclaimed land spreads the area where the surface of the dumped materials is leveled off and prepared for further reclamation - this area has been selected as the case study area and is marked as dark green polygon in Figure 2. The remaining part of the Jóźwin II B dump area and the final excavation of the pit located east from the selected study area is characterized by irregular surface with alternating escarpments, and after taking appropriate engineering measures will form slopes and bottom of a large water reservoir which is planned to be created after ceasing coal excavation in the pit.

The selection of study areas within the Jóźwin II A and II B inner dumping space was discussed with the PAK Konin Lignite Mine and aligns with the Mine's intentions to use these areas for renewable energy generation, if possible. The areas where the surface of the dumped materials is stabilized, leveled off and it reaches more or less the original level from before the lignite excavation were taken into account as well as areas already reclaimed as agricultural lands. On the other hand, areas already reclaimed as recreational sites as well as mine water reservoirs and ponds were excluded. Moreover, only the areas within the above-mentioned dumps which are still in possession of the PAK Konin Lignite Mine were subject to selection. 
The results of preliminary screening of the above locations in terms of legal requirements for renewable energy development are presented in Table 2 and Figures 3-8 for wind energy generation and Table 3, Figures 5, 6 and 8-10 for solar energy generation.

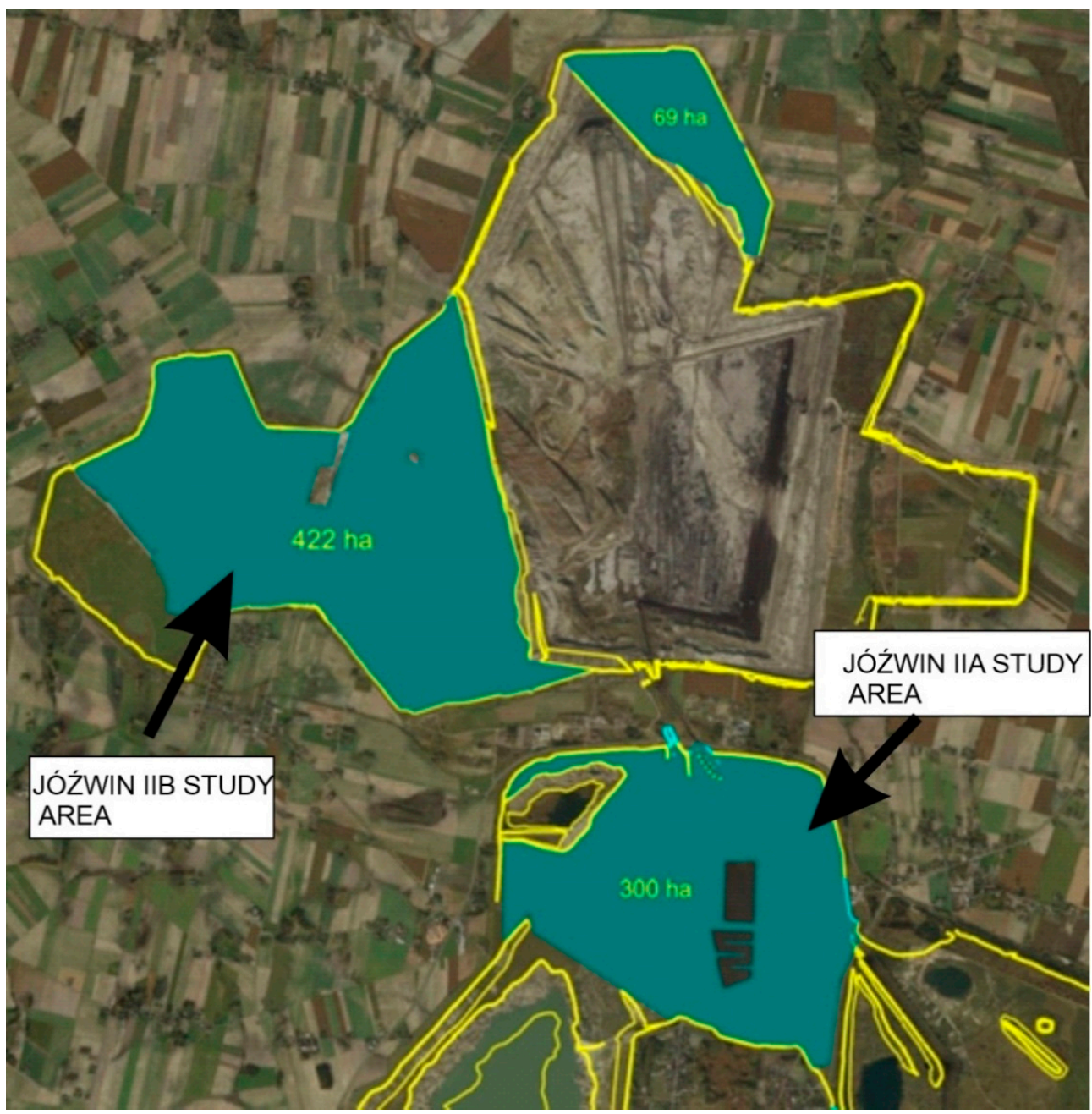

Figure 2. Location and size of the case study areas selected within the dumping space (dark green polygons) of the Konin lignite mining region.

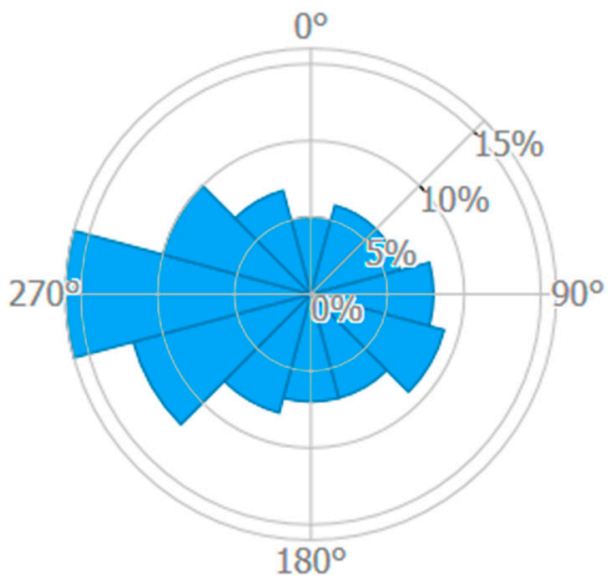

Figure 3. Wind frequency rose (winds at a height of $150 \mathrm{~m}$ ) for the central part of the study area within the Jóźwin IIB open pit inner dumping space (Source: globalwindatlas.info) [51]. 
Table 2. Preliminary screening of the wind farm locations within the selected spoil dump.

Type of a Requirement/Limitation

Energy potential related to meteorological/topographic conditions

The Area within the Jóźwin II B Open Pit inner Dumping Space

- Mean wind speed at a height of $100 \mathrm{~m}-7.6 \mathrm{~m} / \mathrm{s}, 150 \mathrm{~m}-8.7 \mathrm{~m} / \mathrm{s}$, $200 \mathrm{~m}-9.3 \mathrm{~m} / \mathrm{s}$; for wind frequency and wind speed variability see Figures 3 and 4 (Data and figures obtained from the "Global Wind Atlas 3.0, a free, web-based application developed, owned and operated by the Technical University of Denmark (DTU). The Global Wind Atlas 3.0 is released in partnership with the World Bank Group, utilizing data provided by Vortex, using funding provided by the Energy Sector Management Assistance Program (ESMAP). For additional information: https:/ / globalwindatlas.info (accessed on 30 May 2021)") [51]

- The resulting power output must be calculated to prove profitability of the investment

Rights to use the land The land is owned by Konin Lignite Mine

- Conditions unknown

- Adequate subsurface investigation required - it should include sufficient amounts of drilling, sampling and laboratory testing to identify potential

Geotechnical conditions of the site sources of construction difficulties

- Ground investigation report, geotechnical design report and geological-engineering documentation must be delivered in addition to construction design and geotechnical opinion

Grid connection
conditions

Must be agreed with ENERGA-OPERATOR S.A. (regional power grid operator)

- main power point (GPZ) of ENERGA-OPERATOR S.A. located in the direct vicinity of the southern border of the dump (ca. $270 \mathrm{~m}$ southeast in the village of Roztoka, Figure 5)

- PAK KWB Konin's transformer station is located directly at the southern border of the dump, adjacent to the study area (Figure 5)

Possibility of heavy material transportation to the site

- possible-various roads available in the vicinity

- a regional road no. 263 is located ca. $400 \mathrm{~m}$ from the southern border of the dump (Figure 6)

\begin{tabular}{cl}
$\begin{array}{c}\text { Established local land } \\
\text { use plan }\end{array}$ & The plan must indicate possibility for wind power plant construction \\
\hline & $\begin{array}{l}\text { a distance between a wind power plant and a residential area must be at } \\
\text { least ten times larger than a total height of the plant; therefore, several } \\
\text { villages that are located in the immediate vicinity of the dump exclude a } \\
\text { cistance to } \\
\text { construction of } 150 \mathrm{~m} \text { or taller wind power plants (an analysis of distances to } \\
\text { the nearest dwellings is presented in Figure } 7 \text { ) } \\
\text { protection areas }\end{array}$ \\
central part of the study area is located 3-10 km away from the borders of \\
the nearest nature protection areas (Figure 8 )
\end{tabular}

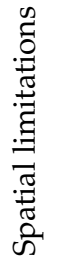

Investment on rural land If the land is reclaimed for agricultural purposes, it will have to be excluded from agricultural use (regardless of the class of agricultural land)

\begin{tabular}{cc}
\hline Distance to public roads & $\begin{array}{c}\text { Minimum distances are specified in the Act for different types of roads. If smaller, } \\
\text { a consent of a relevant road administrator must be obtained }\end{array}$ \\
\hline $\begin{array}{c}\text { Distance to overhead } \\
\text { power transmission lines }\end{array}$ & $\begin{array}{c}\text { Minimum distances are specified by power distribution companies and depend on } \\
\text { voltage of the power lines }\end{array}$ \\
\hline Location of air traffic & No area with limited development of constructed objects due to air traffic in \\
the vicinity
\end{tabular}


Table 2. Cont.

\begin{tabular}{|c|c|c|}
\hline \multicolumn{2}{|c|}{ Type of a Requirement/Limitation } & The Area within the Jóźwin II B Open Pit inner Dumping Space \\
\hline \multirow{5}{*}{ 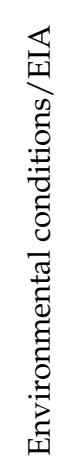 } & $\begin{array}{l}\text { Obtaining decision on } \\
\text { environmental conditions }\end{array}$ & Required \\
\hline & $\begin{array}{l}\text { Location of nature } \\
\text { protection areas }\end{array}$ & impact on the nearest nature protection areas is important in terms of EIA \\
\hline & Acoustic influence & $\begin{array}{l}\text { If a distance between a wind power plant and a residential area must be at least } \\
\text { ten times larger than a total height of the plant, the noise standards are always met }\end{array}$ \\
\hline & $\begin{array}{l}\text { Location of birds and } \\
\text { bats corridors }\end{array}$ & $\begin{array}{c}\text { Monitoring of birds and bats, usually one year-long, is required for an } \\
\text { environmental impact assessment report }\end{array}$ \\
\hline & $\begin{array}{l}\text { Location of } \\
\text { protected landscape }\end{array}$ & Impact on landscape must be analyzed in frame of EIA \\
\hline
\end{tabular}

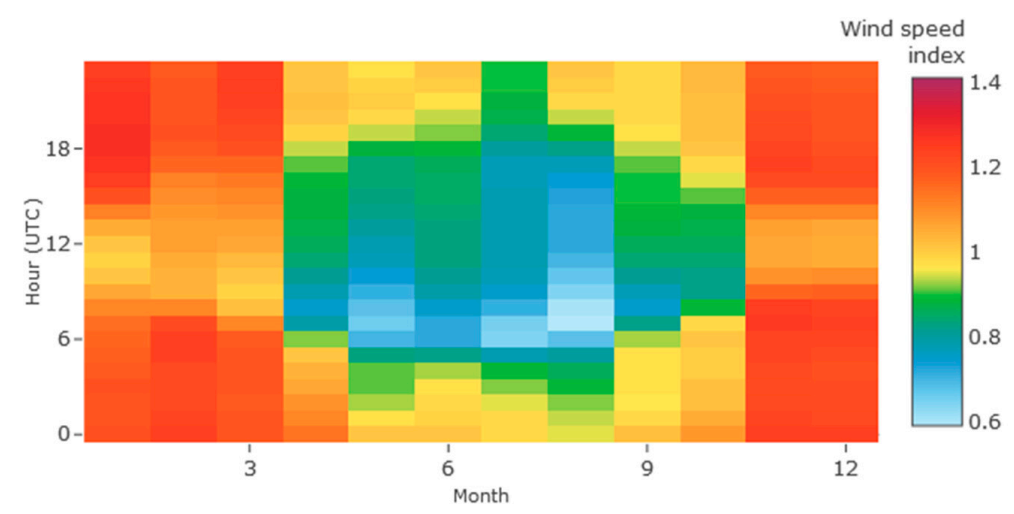

Figure 4. Hourly vs. monthly wind speed variability (winds at a height of $150 \mathrm{~m}$ ) for the central part of the study area within the Jóźwin IIB open pit inner dumping space. Wind speed index places wind speeds in the context of mean speed value, i.e., is the multiplier of the mean annual wind speed (Source: globalwindatlas.info (accessed on 30 May 2021)) [51].

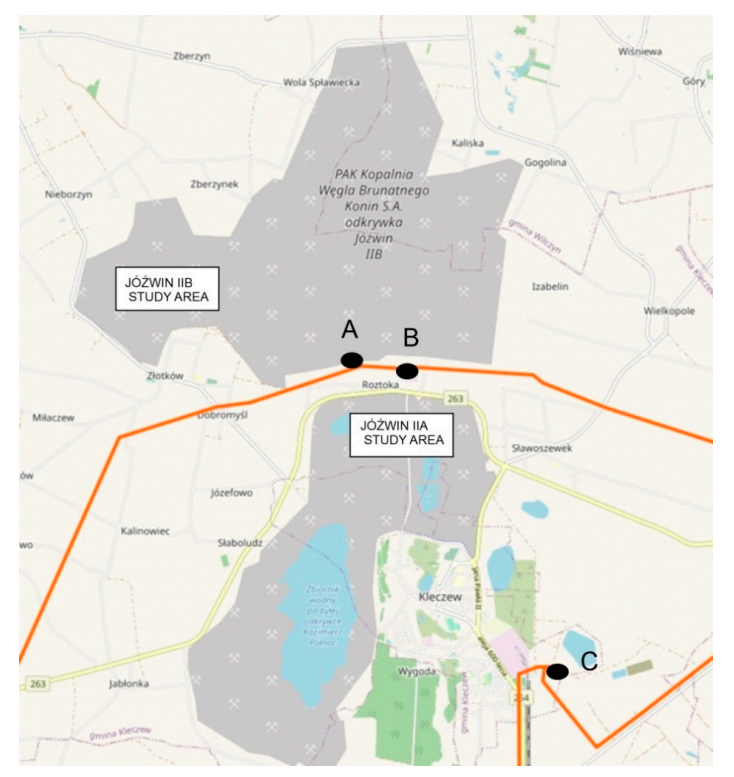

Figure 5. Location of ENERGA OPERATOR's $110 \mathrm{kV}$ power line marked as a red line (Source: OpenStreetMap). A-Jóźwin II transformer station of the Konin Lignite Mine, B-Kleczew transformer station of ENERGA OPERATOR, C-Jóźwin 1 transformer station of the Konin Lignite Mine/PAK KWB Konin S.A. 


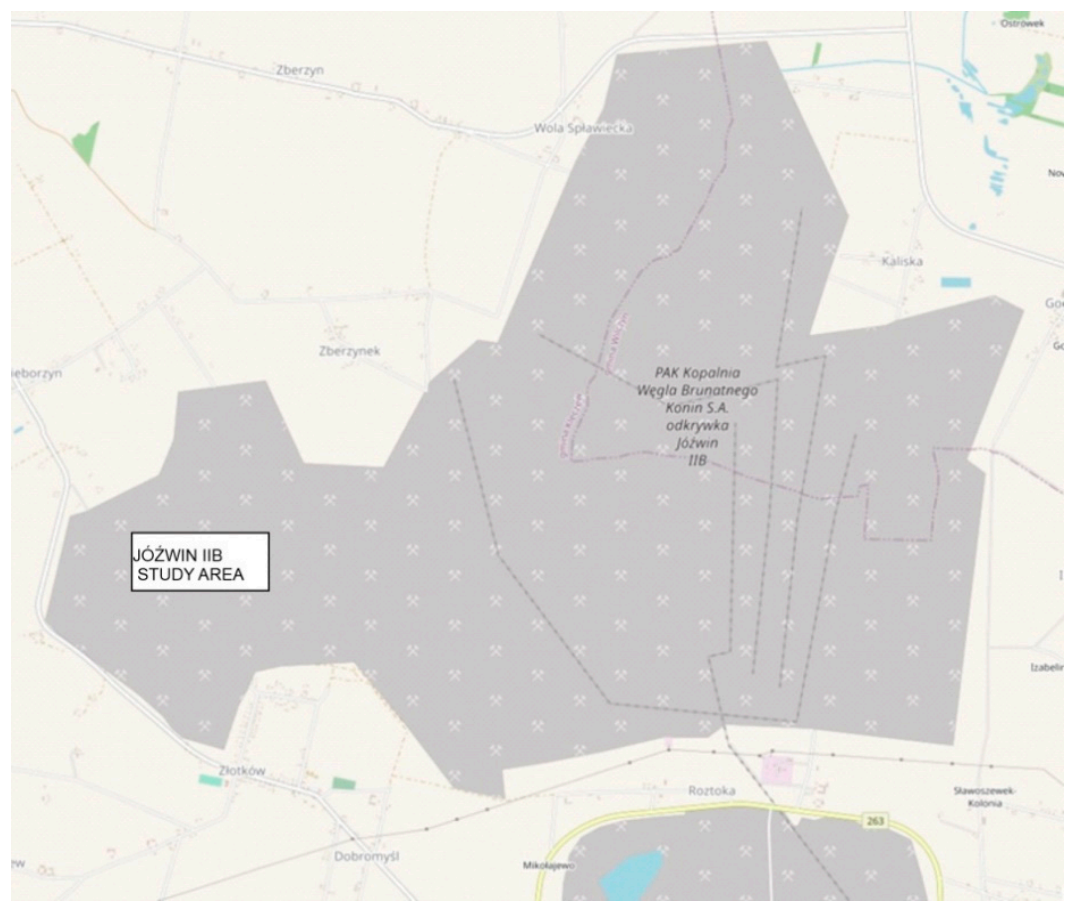

Figure 6. Location of roads and villages surrounding the Jóźwin II B open pit inner dumping area. A regional road no 263 is marked in yellow (Source: OpenStreetMap).

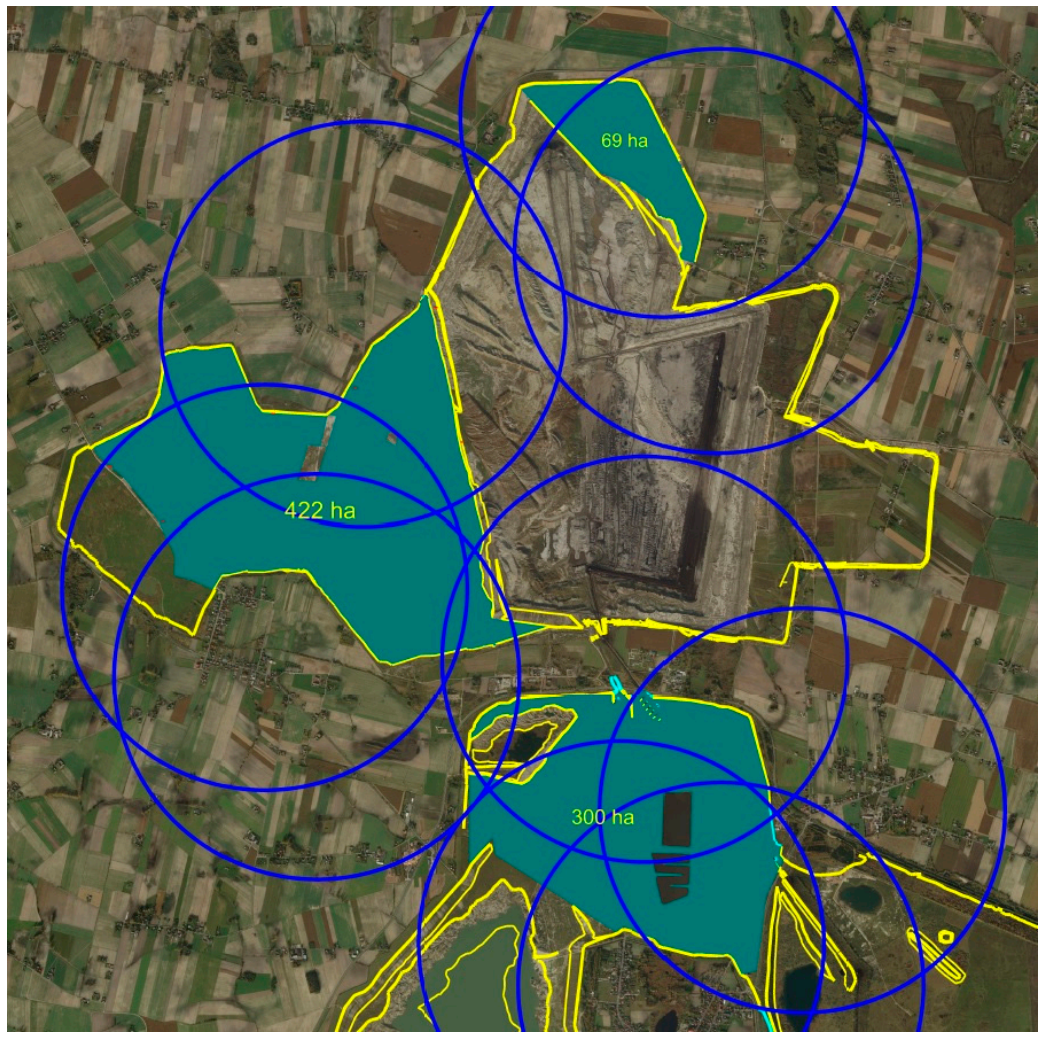

Figure 7. Analysis of distances from the study areas within the Jóźwin IIA and IIB inner dumping space to the nearest dwellings. Dark blue circles indicate distances of $1500 \mathrm{~m}$ from the dwellings located in the closest vicinity of the dumps' borders. The analysis of the circle ranges shows that practically no wind power plant of a height of $150 \mathrm{~m}$ or more can be located in both study areas. 


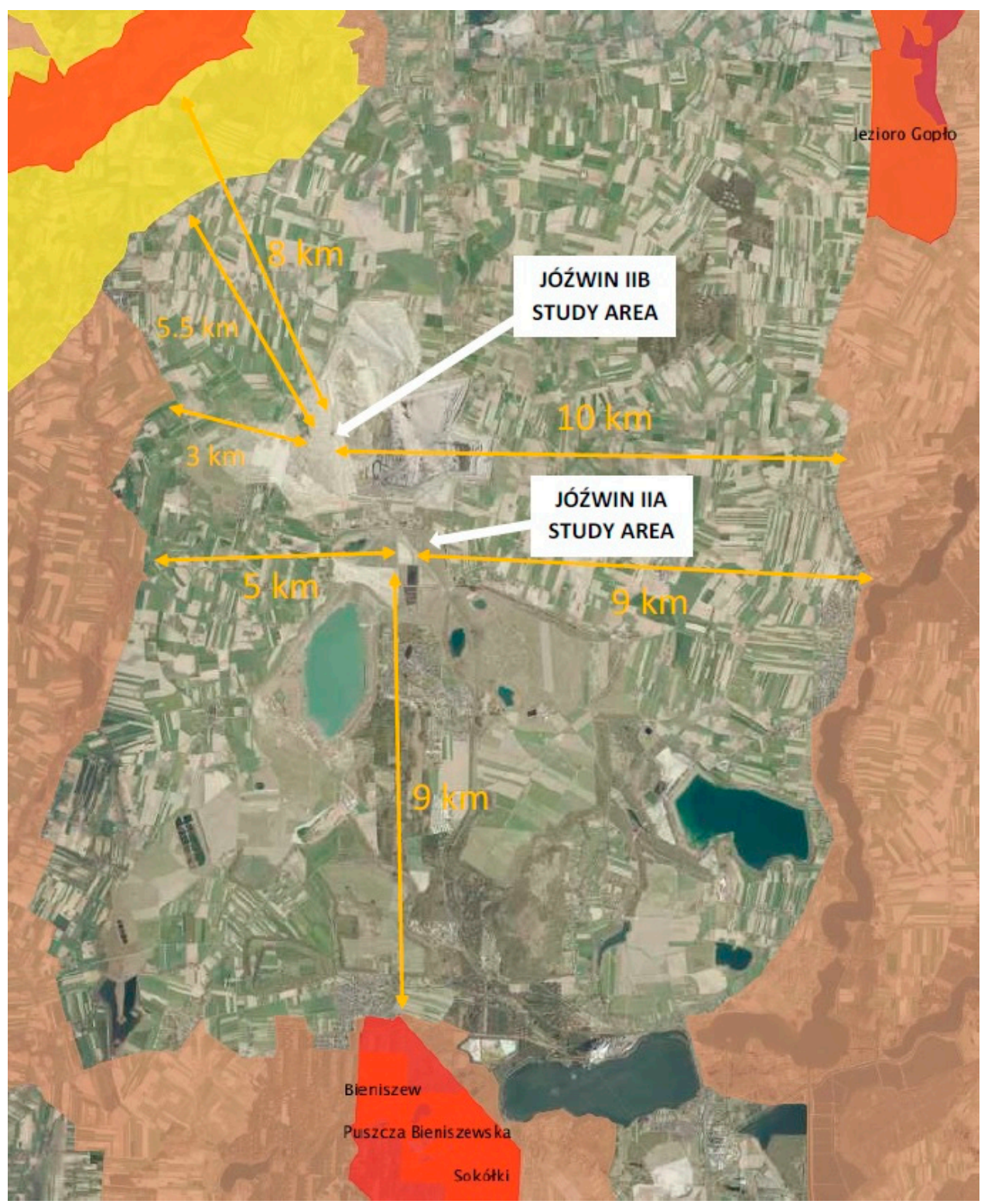

Figure 8. Location of Jóźwin IIA and IIB study areas with respect to nature protection areas (brownprotected landscape area; yellow-landscape park, red-Natura 2000 site; Source: geoportal.gov.pl (accessed on 30 May 2021)) [52]. 
Table 3. Preliminary screening of the solar farm locations within the selected spoil dumps.

\begin{tabular}{|c|c|c|}
\hline $\begin{array}{c}\text { Type of a } \\
\text { Requirement/Limitation }\end{array}$ & $\begin{array}{l}\text { The Area within the Jóźwin IIB inner } \\
\text { Dumping Space }\end{array}$ & $\begin{array}{l}\text { The Area within the Jóźwin IIA inner } \\
\text { Dumping Space }\end{array}$ \\
\hline \multirow{3}{*}{$\begin{array}{l}\text { Energy potential related to } \\
\text { meteorological/topographic } \\
\text { conditions }\end{array}$} & \multicolumn{2}{|l|}{ - Direct normal irradiation $-1015 \mathrm{kWh} / \mathrm{m}^{2} / \mathrm{yr}$} \\
\hline & \multicolumn{2}{|c|}{$\begin{array}{l}\text { Global horizontal irradiation }-1097 \mathrm{kWh} / \mathrm{m}^{2} / \mathrm{yr} \\
\text { Global tilted irradiation at optimum angle }-1307 \mathrm{kWh} / \mathrm{m}^{2} / \mathrm{yr} \\
\text { (Data obtained from the "Global Solar Atlas } 2.0 \text {, a free, web-based application is developed and operated by } \\
\text { the company Solargis s.r.o. on behalf of the World Bank Group, utilizing Solargis data, with funding provided } \\
\text { by the Energy Sector Management Assistance Program (ESMAP). For additional information: } \\
\text { https://globalsolaratlas.info (accessed on } 30 \text { May 2021)) [52]. }\end{array}$} \\
\hline & \multicolumn{2}{|c|}{$\begin{array}{l}\text { The resulting power output must be calculated to prove profitability of an investment. For approximate } \\
\text { calculations see Figure } 10\end{array}$} \\
\hline Rights to use the land & \multicolumn{2}{|c|}{ the land is owned by the Konin Lignite Mine/PAK KWB Konin S.A. } \\
\hline Geotechnical conditions of the site & \multicolumn{2}{|c|}{$\begin{array}{l}\text { Conditions unknown } \\
\text { Adequate subsurface investigation required-it should include sufficient amounts of drilling, sampling } \\
\text { and laboratory testing to identify potential sources of construction difficulties } \\
\text { Ground investigation report, geotechnical design report and geological-engineering documentation } \\
\text { must be delivered in addition to construction design and geotechnical opinion }\end{array}$} \\
\hline \multirow[b]{2}{*}{ 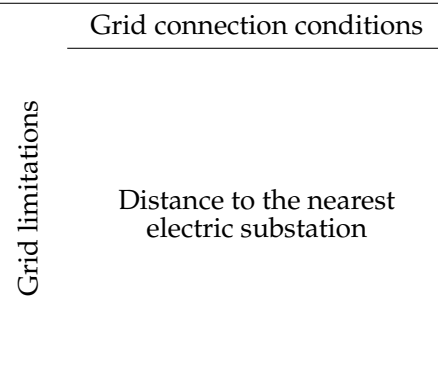 } & \multicolumn{2}{|c|}{ Must be agreed with ENERGA-OPERATOR S.A. (regional power grid operator) } \\
\hline & $\begin{array}{l}\text { - main power point (GPZ) of } \\
\text { ENERGA-OPERATOR S.A. located in the } \\
\text { direct vicinity of the southern border of the } \\
\text { dump (ca. } 270 \mathrm{~m} \text { southeast in the village of } \\
\text { Roztoka, Figure 5) } \\
\text { - PAK KWB Konin's transformer station is } \\
\text { located directly at the southern border of the } \\
\text { dump, adjacent to the study area (Figure 5) }\end{array}$ & $\begin{array}{l}\text { - main power point (GPZ) of } \\
\text { ENERGA-OPERATOR S.A. located in the } \\
\text { direct vicinity of the northern border of the } \\
\text { dump (ca. } 270 \mathrm{~m} \text { north in the village of } \\
\text { Roztoka, Figure 5) } \\
\text { - PAK KWB Konin's transformer stations are } \\
\text { located: } 750 \mathrm{~m} \text { northwest from the northern } \\
\text { part of the study area and } 2.5 \text { km southeast } \\
\text { from the southern part of the study area } \\
\text { (Figure 5) }\end{array}$ \\
\hline \multirow[b]{2}{*}{$\begin{array}{l}\text { Possibility of heavy material } \\
\text { transportation to the site }\end{array}$} & \multicolumn{2}{|c|}{ Possible—various roads available in the vicinity } \\
\hline & $\begin{array}{l}\text { a regional road no. } 263 \text { is located ca. } 400 \mathrm{~m} \text { from the } \\
\text { southern border of the dump (Figure 6) }\end{array}$ & $\begin{array}{l}\text { regional roads no. } 263 \text { and } 264 \text { are adjacent to the } \\
\text { northern and southern parts of the area, respectively } \\
\text { (Figure 9) }\end{array}$ \\
\hline $\begin{array}{l}\text { Established local land } \\
\text { use plan }\end{array}$ & $\begin{array}{l}\text { - The plan must indicate possibility for solar plan } \\
\text { - } \quad \text { if there is no local land use plan established, a z } \\
\text { question must be obtained }\end{array}$ & $\begin{array}{l}\text { construction } \\
\text { oning and land use decision for a plot of land in }\end{array}$ \\
\hline
\end{tabular}

Distance to residential/nature protection areas

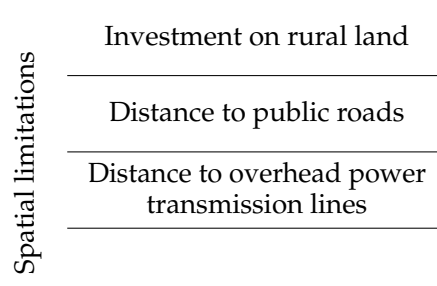

Location of protected landscape
If the land is reclaimed for agricultural purposes, it has to be excluded from agricultural use (regardless of the class of agricultural land)

Minimum distances are specified in the Act for different types of roads. If smaller, a consent of a relevant road administrator must be obtained

Location of a power plant in a close distance to a power line, especially within a technical lane going along the line, must be agreed with a relevant power distribution company

Landscape audit for the Wielkopolska Region, which indicates priority landscapes and landscape protection zones, not yet completed
The nearest landscape protection takes place in the The nearest landscape protection takes place in the protected landscape area called protected landscape area called
Powidzko-Bieniszewski Obszar Chronionego
Krajobrazu located ca. $5 \mathrm{~km}$ west from the study area (Figure 8)

area (Figure 8)
Required for photovoltaic farms covering the area larger than 1 ha




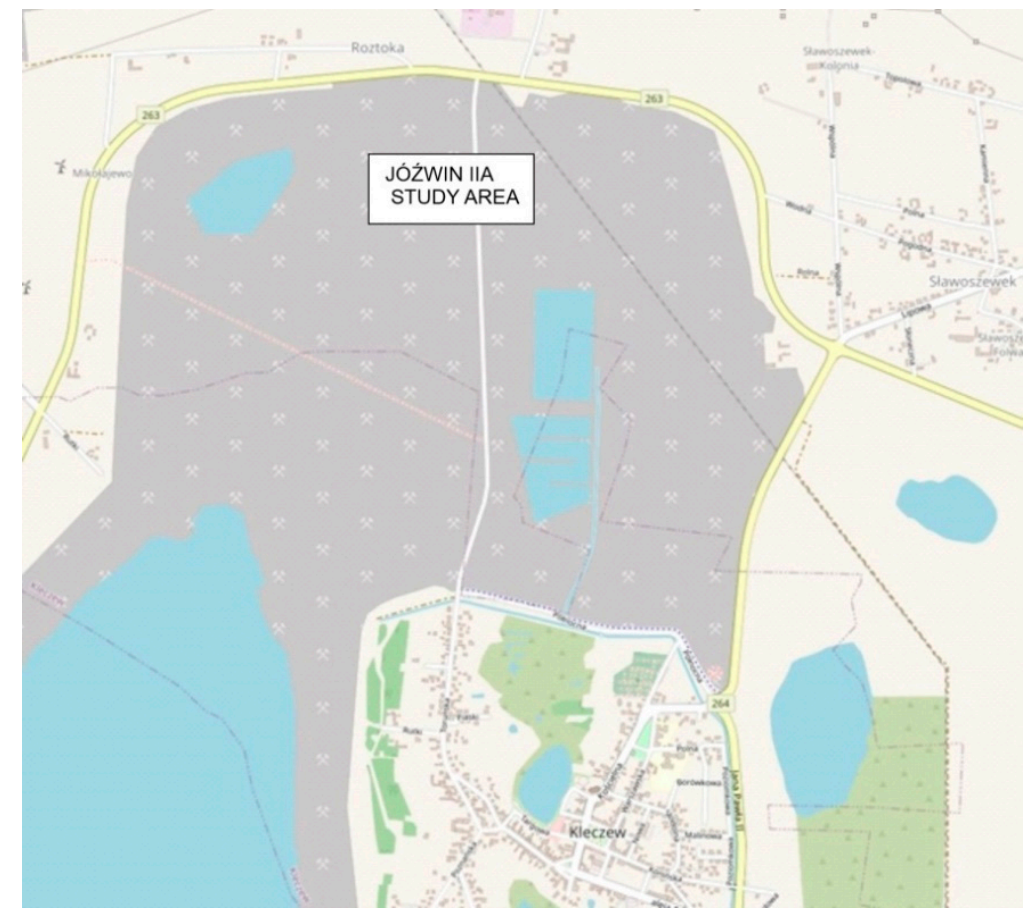

Figure 9. Location of roads, villages and Kleczew town near the Jóźwin II A study area. Regional roads no 263 and 264 are marked in yellow (Source: OpenStreetMap).

\section{Average hourly profiles}

Total photovoltaic power output [kWh]

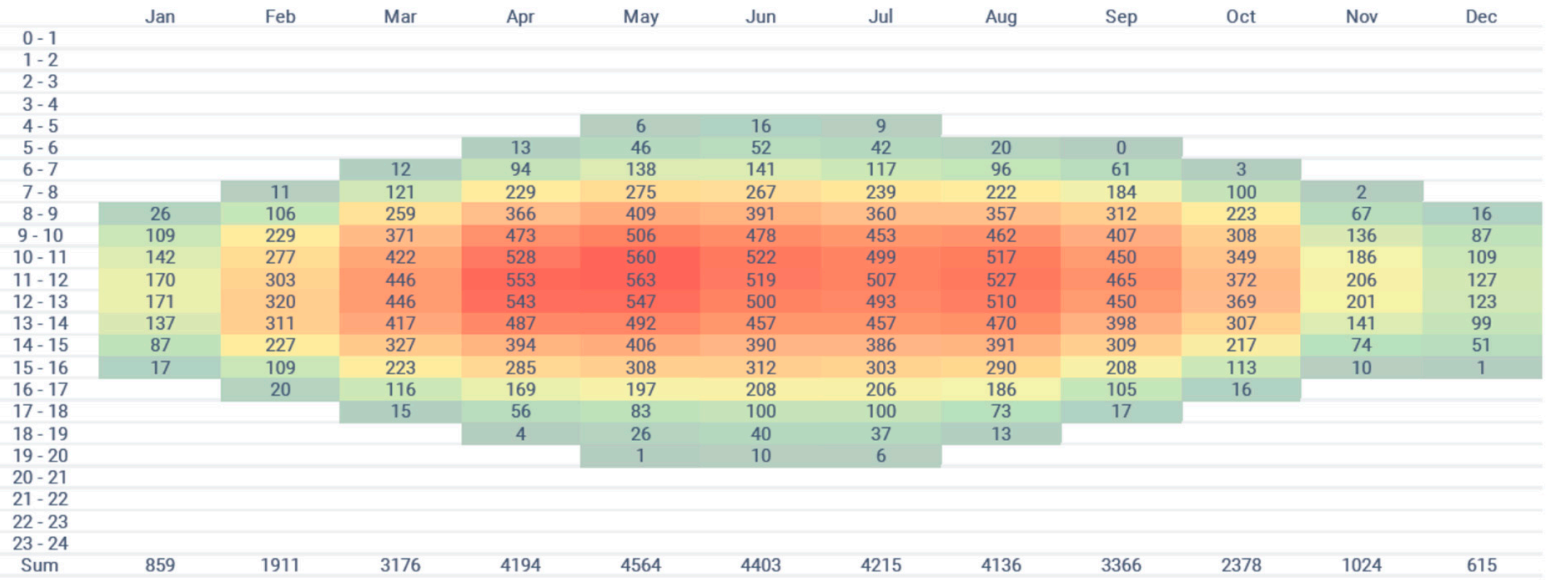

Figure 10. Total photovoltaic power output through the year [kWh] for the study area within the Jóźwin IIB Mine inner dump. Data and image obtained from the "Global Solar Atlas 2.0, a free, web-based application is developed and operated by the company Solargis s.r.o. on behalf of the World Bank Group, utilizing Solargis data, with funding provided by the Energy Sector Management Assistance Program (ESMAP). For additional information: https:/ / globalsolaratlas.info (accessed on 30 May 2021) [53].

\section{Discussion}

The location a renewable energy plant in a certain place depends on many factors. First of all, it must have suitable and stable conditions of wind or sunlight. It is also important what purpose of a given area is set in municipal planning documents. However, the in case of location of a wind or solar farm in post-mining areas, the most important issue seems to be whether the land built of overburden disposal spoil material or mine waste material 
dumped for many years of mine operations is suitable for the construction of this type of installation. Therefore, a detailed geotechnical analysis based on field research has to be performed.

Apart from natural conditions affecting potential power generation and construction process and spatial planning conditions, there are other legal constraints such as grid connection limitations or other technical issues which all in all make a wind or solar farm investment within a mining spoil dump a challenging process.

Among the legal conditions for the construction of renewable energy plants, the most restrictive limitation concerns wind farms. In July 2016, the provisions of the Act of on wind farm investments came into force. According to these provisions, wind power plants can be constructed away from residential buildings at distances at least 10 times larger than total wind power plant heights (it is so called " $10 \mathrm{~h}$ rule"). In practice, it is $1.5-2 \mathrm{~km}$ or even more, considering the fact that with a rapid development of wind technology, taller wind power plants with higher power outputs are designed. The same distance must be kept when constructing new wind power plants near nature protection areas such as national parks, nature reserves, landscape parks or Natura 2000 sites. These very strict regulations have caused that construction of tall and efficient wind turbines is impossible almost all over the country.

In 2020, the Polish government started work on amending the act which aimed at relaxing the $10 \mathrm{~h}$ rule. On the 4 May 2021 Polish Government Legislation Center published the Draft act amending the act on wind farm investments and certain other acts for purposes of public consultations [54]. According to the draft amendment, wind turbines could only be located on the basis of local land use plans, in which municipalities indicate minimum distances from wind power plants to residential buildings. These distances might be less than " $10 \mathrm{~h}$ "(which still stays as a general rule) but not less than $500 \mathrm{~m}$. Such land use plans must be adopted based on results of environmental impact assessments accompanied by additional public consultations. The amendment is expected to be adopted in 2021. It is generally anticipated that after the amendment, the construction of wind farms will be possible at closer distances to residential buildings, which will enable rehabilitation of Konin mining spoil dumps in this direction. Until then, photovoltaic power plants are the only option for the development of post-mining areas towards large-scale renewable power generation.

Author Contributions: Conceptualization, M.R. and B.R.; methodology, formal analysis, investigation, M.R.; resources, M.R. and M.D.; writing—original draft preparation, M.R.; writing—review and editing, B.R., J.S. and M.D.; supervision, J.S.; project administration, B.R.; funding acquisition, B.R. All authors have read and agreed to the published version of the manuscript.

Funding: This research was funded by the Research Fund for Coal and Steel, grant number 847227 and the program of the Minister of Science and Higher Education entitled "PMW" in 2019-2022; grant number 5029/FBWiS/2019/2.

Data Availability Statement: Publicly available data, maps and figures were analyzed in this study. This data can be found here: globalwindatlas.info, globalsolaratlas.info, geoportal.gov.pl, openstreetmap.org (accessed on 30 May 2021).

Acknowledgments: The authors would like to acknowledge the essential contribution of the Konin Lignite Mine (PAK Kopalnia Wẹgla Brunatnego Konin S.A.) to the RFCS SUMAD project. Special thanks go to Mateusz Markowski for his kind assistance in preparing the figures for this paper. The authors are also grateful to the reviewers for their comments that helped to improve the manuscript.

Conflicts of Interest: The authors declare no conflict of interest. 


\section{References}

1. The European Green Deal. Communication from the Commission to the European Parliament, the European Council, the Council, the European Economic and Social Committee and the Committee of the Regions. COM (2019) 640 Final. Available online: https:/ / eur-lex.europa.eu/legal-content/EN/TXT/?uri=CELEX:52019DC0640 (accessed on 28 December 2021).

2. Directive (EU) $2018 / 2001$ of the European Parliament and of the Council of 11 December 2018 on the Promotion of the Use of Energy from Renewable Sources (Text with EEA Relevance.) PE/48/2018/REV/1. OJ L 328, 21.12.2018, pp. 82-209. Available online: https:/ / eur-lex.europa.eu/eli/dir/2018/2001/oj (accessed on 28 December 2021).

3. Proposal for a Directive of the European Parliament and of the Council amending Directive (EU) 2018/2001 of the European Parliament and of the Council, Regulation (EU) 2018/1999 of the European Parliament and of the Council and Directive 98/70/EC of the European Parliament and of the Council as Regards the Promotion of Energy from Renewable Sources, and Repealing Council Directive (EU) 2015/652. COM/2021/557 Final. Available online: https:/ / eur-lex.europa.eu/legal-content/EN/TXT/ ?uri=CELEX:52021PC0557 (accessed on 28 December 2021).

4. Marks-Bielska, R.; Bielski, S.; Pik, K.; Kurowska, K. The Importance of Renewable Energy Sources in Poland's Energy Mix. Energies 2020, 13, 4624. [CrossRef]

5. Serowaniec, M. Sustainable Development Policy and Renewable Energy in Poland. Energies 2021, 14, 2244. [CrossRef]

6. Kosiorek, K.; Jarzynka, A. Renewable energy sources in legal terms. Kortowski Przeglad Praw. 2017, 1, 163-169, (In Polish with English abstract).

7. Dolega, W. Problems, Barriers and Perspectives of RES Development in Poland. In Power Systems, Energy Markets and Renewable Energy Sources in South-Eastern Europe; Mavromatakis, F., Siderakis, K., Eds.; Trivent Publishing: Budapest, Hungary, 2016; Volume 3, pp. 265-282.

8. Przybylska-Czastkiewicz, M. Legal conditions for the development of renewable energy in Poland after 2015. Polityka Energetyczna Energy Policy J. 2017, 20, 103-116, (In Polish with English abstract).

9. Stolińska, B. The factors of wind turbines location. Świat Nieruchom. 2014, 88, 27-31, (In Polish with English abstract).

10. Energetyka Wiatrowa. Kodeks Dobrych Praktyk. PSEW 2019. Available online: http://psew.pl/biblioteka/opracowania/ (accessed on 30 September 2021).

11. Igliński, B.; Iglińska, A.; Koziński, G.; Skrzatek, M.; Buczkowski, R. Wind energy in Poland-History, current state, surveys, Renewable Energy Sources Act, SWOT analysis. Renew. Sustain. Energy Rev. 2016, 64, 19-33. [CrossRef]

12. Zajdler, R. Regulacje Prawa Krajowego Dotyczace Inwestycji w Farmy Wiatrowe (Wybrane Aspekty); Instytut Sobieskiego: Warszawa, Poland, 2012.

13. Stryjecki, M.; Mielniczuk, K.I. Wytyczne w Zakresie Prognozowania Oddziaływań na Środowisko Farm Wiatrowych; Generalna Dyrekcja Ochrony Środowiska: Warszawa, Poland, 2011.

14. Majer, E.; Sokołowska, M.; Frankowski, Z. (Eds.) Zasady Dokumentowania Geologiczno-Inżynierskiego (w Świetle Wymagań Eurokodu 7); Państwowy Instytut Geologiczny-Państwowy Instytut Badawczy: Warszawa, Poland, 2018.

15. Sobieski, G.; Zaremba, A.; Stankiewicz, D.; Dalak, D. Posadowienie turbin wiatrowych w kontekście nowego systemu wsparcia OZE. Paliwa Energetyka 2016, 1, 60-63.

16. Pardela, T. Posadowienie wysokich wież elektrowni wiatrowych o mocy 2.0-2.5 MW na słabym podłożu gruntowym. Nowocz. Bud. Inżynieryjne 2012, 3, 70-73.

17. Utility-Scale Solar Photovoltaic Power Plants: A Project Developer's Guide; International Finance Corporation: Washington, DC, USA, 2015.

18. Łaganowska, Z. Prawne aspekty budowy farmy PV. Globnergia 2013, 3, 40-42.

19. Przywoźna, A. Poradnik Inwestora Fotowoltaicznego (cz. 1). Ambiens Sp. z o.o. 2013. Available online: http://www.ambiens. $\mathrm{pl} / \mathrm{blog}$ /poradnik-inwestora-fotowoltaicznego-1/ (accessed on 25 March 2021).

20. Przywoźna, A. Poradnik Inwestora Fotowoltaicznego (cz. 2). Ambiens Sp. z o.o. 2013. Available online: http://www.ambiens. $\mathrm{pl} / \mathrm{blog}$ /poradnik-inwestora-fotowoltaicznego-2/ (accessed on 25 March 2021).

21. Zwolińska-Mańczak, A.; Tarka, M. 2013: Przeprowadzanie ocen oddziaływania farm fotowoltaicznych na środowisko. Paliwa Energetyka 2013, 3, 70-73.

22. Więcka, A.; Zarzeczna, J. Rynek Fotowoltaiki w Polsce 2019; EC BREC Instytut Energetyki Odnawialnej Sp. z o.o.: Warszawa, Poland, 2019; 65p.

23. Farcas, V.; Ilies, N. Aspects Regarding Soil Investigation and Foundation Design for Photovoltaic Power Plants. In International Congress on Energy Efficiency and Energy Related Materials (ENEFM2013); Oral, A., Bahsi, Z., Ozer, M., Eds.; Springer Proceedings in Physics; Springer: Cham, Switzerland, 2014; Volume 155, pp. 391-396.

24. Annavarapu, S.; Wilson, T.; Momayez, M.; Cronin, A. Geotechnical considerations for solar panel installation on mine tailings. In Proceedings of the 26th Annual Meetings of the American Society of Mining and Reclamation and 11th Billings Land Reclamation Symposium 2009; American Society of Mining and Reclamation: Lexington, KY, USA, 2009; Volume 1, pp. $37-43$.

25. Foks, A.; Całka, B.; Bielecka, E. Torzym Multi-criteria spatial analysis in search of the potential location of solar farms in Torzym commune. Polskie Towarzystwo Informacji Przestrzennej. Roczniki Geomatyki 2019, 3, 171-182, (In Polish with English abstract).

26. Hajto, M.; Cichocki, Z.; Bidłasik, M.; Borzyszkowski, J.; Kuśmierz, A. Constraints on Development of Wind Energy in Poland due to Environmental Objectives. Is There Space in Poland for Wind Farm Siting? Environ. Manag. 2017, 59, 204-217. [CrossRef] [PubMed] 
27. Synowiec, W.; Luc, M. A multicriterial evaluation of land suitability for wind energy development, as exemplified by Poland's gmina of Rymanów. Przegląd Geogr. 2013, 85, 323-352, (In Polish with English abstract). [CrossRef]

28. Wang, Q.; M'Ikiugu, M.M.; Kinoshita, I.; Luo, Y. GIS-Based Approach for Municipal Renewable Energy Planning to Support Post-Earthquake Revitalization: A Japanese Case Study. Sustainability 2016, 8, 703. [CrossRef]

29. Zalhaf, A.S.; Elboshy, B.; Kotb, K.M.; Han, Y.; Almaliki, A.H.; Aly, R.M.H.; Elkadeem, M.R. A High-Resolution Wind Farms Suitability Mapping Using GIS and Fuzzy AHP Approach: A National-Level Case Study in Sudan. Sustainability 2022, 14, 358. [CrossRef]

30. Regulation (EU) 2021/1056 of the European Parliament and of the Council of 24 June 2021 Establishing the Just Transition Fund. PE/5/2021/REV/1. OJ L 231, 30.6.2021, pp. 1-20. Available online: https:/ / eur-lex.europa.eu/eli/reg/2021/1056/oj (accessed on 28 December 2021).

31. Regulation of the Minister of Environment of 24 April 2012 on Detailed Requirements for Deposit Development Projects (Journal of Laws of 2012, item 511). Available online: http:/ /isap.sejm.gov.pl/isap.nsf/DocDetails.xsp?id=WDU20120000511 (accessed on 30 September 2021).

32. Regulation of the Minister of the Environment of December 8, 2017 on Mining Plant Operation Plans (Journal of Laws of 2017, item 2293). Available online: http:/ /isap.sejm.gov.pl/isap.nsf/DocDetails.xsp?id=WDU20170002293 (accessed on 30 September 2021).

33. Act of February 3, 1995 on the Protection of Agricultural and Forest Land (Journal of Laws 2017, item 1161). Available online: http:/ /isap.sejm.gov.pl/isap.nsf/DocDetails.xsp?id=WDU20170001161 (accessed on 30 September 2021).

34. Act of May 20, 2016 on Wind Farm Investments (Journal of Laws of 2016, item 961). Available online: https: / / isap.sejm.gov.pl/ isap.nsf / DocDetails.xsp?id=WDU20160000961 (accessed on 30 September 2021).

35. Act of 7 July 1994 Construction Law (Journal of Laws of 2020, item 1333). Available online: https:/ / isap.sejm.gov.pl/isap.nsf/ DocDetails.xsp?id=WDU20200001333 (accessed on 30 September 2021).

36. Regulation of the Minister of Transport, Construction and Maritime Economy of 25 April 2012 on the Determination of Geotechnical Conditions for the Foundation of Buildings (Journal of Laws of 2012, item 463). Available online: http:/ / isap.sejm.gov.pl/ isap.nsf/DocDetails.xsp?id=WDU20120000463 (accessed on 30 September 2021).

37. Act of 9 June 2011 Geological and Mining Law (Journal of Laws 2020, item 1064). Available online: https:/ / isap.sejm.gov.pl/isap. nsf/DocDetails.xsp?id=WDU20200001064 (accessed on 30 September 2021).

38. Regulation of the Minister of the Environment of November 18, 2016 on Hydrogeological Documentation and GeologicalEngineering Documentation (Journal of Laws of 2016, item 2033). Available online: http:/ / isap.sejm.gov.pl/isap.nsf/DocDetails. xsp?id=WDU20160002033 (accessed on 30 September 2021).

39. Act of April 10, 1997 Energy Law (Journal of Laws 2020, item 833). Available online: https:/ /isap.sejm.gov.pl/isap.nsf/DocDetails. xsp?id=WDU20200000833 (accessed on 30 September 2021).

40. Act of 27 March 2003 on Spatial Planning and Development (Journal of Laws of 2020, item 293). Available online: https: / / isap.sejm.gov.pl/isap.nsf/DocDetails.xsp?id=WDU20200000293 (accessed on 30 September 2021).

41. Act of March 21, 1985 on Public Roads (Journal of Laws 2020, item 470). Available online: http://isap.sejm.gov.pl/isap.nsf/ DocDetails.xsp?id=WDU20200000470 (accessed on 30 September 2021).

42. Regulation of the Minister of Infrastructure of February 6, 2003 on Occupational Health and Safety during Construction Works (Journal of Laws 2003, No. 47, item 401). Available online: http:/ / isap.sejm.gov.pl/isap.nsf/DocDetails.xsp?id=WDU20030470401 (accessed on 30 September 2021).

43. Regulation of the Minister of Health of 17 December 2019 on the Permissible Levels of Electromagnetic Fields in the Environment (Journal of Laws of 2019, item 2448). Available online: http:/ / isap.sejm.gov.pl/isap.nsf/DocDetails.xsp?id=WDU20190002448 (accessed on 30 September 2021).

44. Act of July 3, 2002, Aviation Law (Journal of Laws 2020, item 1970). Available online: https:/ / isap.sejm.gov.pl/isap.nsf/DocDetails. xsp?id=WDU20200001970 (accessed on 30 September 2021).

45. Act of April 24, 2015 Amending Certain Acts in Connection with the Strengthening Of Landscape Protection Tools (Journal of Laws of 2015, item 774). Available online: http:/ / isap.sejm.gov.pl/isap.nsf/DocDetails.xsp?id=wdu20150000774 (accessed on 30 September 2021).

46. Act of April 16, 2004 on Nature Protection (Journal of Laws of 2020, item 55). Available online: http://isap.sejm.gov.pl/isap.nsf/ DocDetails.xsp?id=WDU20200000055 (accessed on 30 September 2021).

47. Act of 27 April 2001 Environmental Protection Law (Journal of Laws 2020, item 1219). Available online: https://isap.sejm.gov.pl/ isap.nsf/DocDetails.xsp?id=WDU20200001219 (accessed on 30 September 2021).

48. Act of 3 October 2008 on the Provision of Information about the Environment and Its Protection, Public Participation in Environmental Protection and Environmental Impact Assessments (Journal of Laws 2020, item 283). Available online: https: / / isap.sejm.gov.pl/isap.nsf/DocDetails.xsp?id=WDU20200000283 (accessed on 30 September 2021).

49. Regulation of the Council of Ministers of September 10, 2019 on Projects That May Significantly Affect the Environment (Journal of Laws 2019, item 1839). Available online: https:/ /isap.sejm.gov.pl/isap.nsf/DocDetails.xsp?id=WDU20190001839 (accessed on 30 September 2021).

50. Regulation of the Minister of the Environment of 14 June 2007 on Permissible Noise Levels in the Environment (Journal of Laws of 2014, item 112). Available online: httpshttp:/ / isap.sejm.gov.pl/isap.nsf/DocDetails.xsp?id=WDU20140000112 (accessed on 30 September 2021). 
51. Global Wind Atlas. Available online: https:/ /globalwindatlas.info (accessed on 30 May 2021).

52. Geoportal Krajowy. Available online: https://www.geoportal.gov.pl/ (accessed on 30 May 2021).

53. Global Solar Atlas. Available online: https:/ / globalsolaratlas.info (accessed on 30 May 2021).

54. Projekt Ustawy o Zmianie Ustawy o Inwestycjach w Zakresie Elektrowni Wiatrowych Oraz Niektórych Innych Ustaw. Rządowy Proces Legislacyjny. Available online: https://legislacja.rcl.gov.pl/projekt/12346353/katalog/12785203\#12785203 (accessed on 30 September 2021). 